\title{
Sales Force Effectiveness through Technical Skills - An Empirical Observation in Indian Pharmaceutical Industry
}

\author{
Dr. C. R. Sundara Rajan* \\ Dr. K. Sakthi Srinivasan* \\ *Associate Professor, VIT Business School, VIT University, Vellore-632 014, Tamilnadu India \\ Email:crsundararajan@vit.ac.in;trksundararajan@gmail.com \\ ** Professor, VIT Business School, VIT University, Vellore-632 014, Tamilnadu, India; Email: ksakthisrinivasan@vit.ac.in
}

Doi:10.5901/mjss.2015.v6n6s2p641

\begin{abstract}
The study is an attempt to identify the technical skills adopted by sales people in a pharmaceutical industry. The main objective is to understand how far these skills enhance the effectiveness of these sales people when they are in the field. This study is conducted based on survey research and a minimal usage of statistics brought out significant results. The major findings of this study points out the customer/product knowledge and client evaluation are some basic skill sets, which improves the sales people performance in this industry.
\end{abstract}

Keywords: sales force effectiveness, technical skills, buyer/seller relationships, customer and product knowledge

\section{Introduction}

Sales are the lifeblood for any industry. Quarterly results announced by firms in each industry throughout many years speaks only the volume of sales and how it has improved the revenue and profit for them. This is not different with pharmaceutical industry. In this industry, without sales team, revenue for further research and new drugs is difficult. Sales personals involved in this task in today's world are doing multitasking in their job. This definitely has a positive result for both the company and sales people. Since, sales by nature is a task that is to be done in a very tough and competitive environment, sales people need special skills to reach sales target. If they have to add new clients or new accounts, then it is different level of competition. This necessitates the firms to train them as and when it is required. However, the question remains whether this training and frequent recognition alone improves the sales performance?

Efficiency in terms of effectiveness in sales completion is what the firms needed. Understanding effectiveness needs some psychological attitudes of an individual. The term 'effectiveness' is measured through different attributes. These factors comprises of specific objective based outcomes, skill sets controlling the sales persons' behavior, performance results in terms of sales units/volume, revenue generated, profitability, new accounts created, etc. To meet the sales targets, address the competition and ensure the sustainability for long term, the measurement of sales person's effectiveness is inevitable features of business. The continuous measurement of sales force effectiveness provide better clarity about the sales persons' efficiency level in the dynamic business environment.

The understanding of the skill sets of the sales force can help individuals and team performance. This research focus to find out the necessary technical skills required for the better performance of the front line sales force who are engaged in selling branded pharmaceutical products. Further, it adds a clear insight to the pharmaceutical sales managers about the priorities of the skill sets for success of their field sales force.

\section{Sales Force Effectiveness}

Studies pertaining to sales person's actual performance in the field (Churchill et al. 1993, 2000) where the internal (sales individuals) and external factors (working environment) influence level of effectiveness. Thus, the sales person's effectiveness is the result which is influenced by factors which are not subject to his/her control, called as non-personal factors or organizational variables (Grant and Cravens 1999; Pierchy et al 2001; Roman et al, 2002; Churchill et al., 2000; Churchill et al., 1985; Baldauf et al., 2001). In 1994, Sujan et al., suggested that the rapid changes influenced the salespeople towards their sales strategy and lead to higher customer satisfaction and sales effectiveness. Keller's (2000) 
study measured the relationship based characteristics and individual performance of a sales person by three scales such as selling orientation and customer orientation(SOCO), adaptability and SERVE scale. Kelly (1992) mentioned the customer orientation to be the important attribute for the high performers.

Technical Knowledge refers to sales people providing maximum information about the design and its specifications, its functions and application of the products and services. Similarly, the study conducted by Piercy et al., (1997) and Babakus et al., (1996) found a positive relationship between the technical knowledge of the sales people and their outcome performance for an organization effectiveness. Weitz (1981) defined the adaptive selling as the sales person's ability to alter his/her sales behavior when interacting with customers.

The sales performance has been measured as a straight outcome of sales persons' attitude, aptitude, role clarity, skills sets and environmental factors (Churchill et al., 1985). In addition, the mentioned factors are identified as important for the sales process and the time spent on each activity may vary with different degree of weight being placed on each activities. Cravens et al., (1993) found that there existed a relationship between sales persons' behavioral performance and sales organization effectiveness. A positive correlation has been identified between behavior performance and outcome performance in US sales person study conducted by Oliver and Anderson (1994). The study conducted by Babakus et al., (1996), looked at the behavior performance which includes the adaptive selling behavior, technical knowledge of the sales person, sales presentations, sales plan and sales support from the organization. In the same way, Cravens et al., (1993) conducted a research on chief sales executives and examined the technical skills, sales presentations, control over the expenses and providing information for organizations' sales effectiveness.

\section{Literature Survey}

Research discussions have sought to describe the various factors that constitute a salesperson's performance, understand the attributes that influences their performance, identify and control a salesperson's performance. As the salespersons are directly representing an organization to meet customers, the role of sales personnel is of highly potential. Behavior-based measures of salespersons' performance are impactful in the long term. Typical sales behaviors include prospecting, fact finding, selling, closing and servicing customers. In a revelatory study only 10 per cent of work time of a salesperson is spent in active selling, while travel and other sales activity occupy the remaining major portion of time.

Basir, M.S. (2010), the impact of four dimensions of sales skills namely interpersonal skills, salesmanship skills, technical skills and marketing skills as independent variables on the dependent variable namely salesperson performance.

In 2008, Kuster et al., identified determinants of sales force effectiveness. It referred to seven blocks including sales control in the form of follow-up, evaluation and rewards, professionalism in attitude and competencies, sales people's behavior performance in the form of adaptive selling behavior, sales interviews, and sales people's outcome performance. Sales people's behavior based control, their outcome performance, professionalism and sales people's behavior performance were associated with higher sales force effectiveness. It was observed that the least effective teams were especially concerned about clinching deals rather than maintenance of long-term relationships with customers.

Ahearne, M. J., Mathieu, J. E., \& Rapp, A. (2007) studied the importance of social-psychological factors related to the success of sales force technology interventions. Reviewing the influence of the introduction of a new set of technology tools on the performance of salespersons, they found evidence to confirm their hypothesis that the salespersons' work experience would have a negative effect on their technology self-efficacy, which in turn would relate positively to their use of technology. Similarly, Sales performance was found to be positively related to both past performance and the use of new technology tools. Further, the authors hypothesized that leaders' commitment to sales technology would enhance salespersons' technology self-efficacy and usage, and leaders' empowering behaviors would influence salespersons' technology self-efficacy and moderate the individual-level relationships. Hierarchical linear modeling analyses confirmed all of the hypothesized individual-level relationships and most of the cross-level relationships stemming from average leader behaviors. Empowering leadership especially exhibited multiple cross-level interactions.

Analysis by Weiss, L.W., Pascoe, G and Martin, S (1983) found that selling expense ratios were among the highest in the selling of proprietary drugs, where it extends to the tune of over 58 per cent of the retail-selling price.

Pendharkar, A and Pandey, V.K (2010) in a study that aimed at identifying relation between sales profile and sales performance, concluded that factors in the sales profile test namely combative, sales acumen, prospection and technical expertise significantly correlated with the performance of the sales people in a variety of sales jobs. 
Toytari, $\mathrm{P}$ et al. (2011) focused on value based selling in contrast to product based selling. Describing Value as the perceived or real difference between giving and getting and value-based selling as the understanding and improving the customer's business in a proactive manner, the researchers found that offering is most attractive for value-based sales when the real value of the offering is either underestimated or unknown.

Barker, A.T. (2001) looked at the antecedents of sales organization's performance. The study identified various features of highly effective firms in term of sales volume, market share, customer satisfaction and profitability, than those of their competitors.

It was found that establishing long term relationship through sales support and enthusiastic service was a major feature of these firms.

\section{Statement of the Problem}

Pharmaceutical industry is highly organized, technical, scientific and high competitive in nature. Selling medicines to Doctors and pharmacy needs special skills. Sales forces in a pharmaceutical company do possess these skills, but does it prove to be effective? This has to be tested with the results these sales team are getting. Sometimes, new accounts or clients would have been added by a sales team without any special skills. Another team would be reaching the sales target regularly with ease. However, when we study those inter related patterns; it would be surprising that this team do not have any distinct skills. Studies show that effectiveness in sales force is only because of some specific skill sets. Therefore, the study aims to a degree to investigate the competencies required for front line sales force performance. It is believed that this study will add some effective inputs to understand the selling strategies required for better sales performance.

\section{Objectives of the Study}

The important purpose of the study is to scrutinize the perceived attributes considered as essential technical skill set factors for the sales force effectiveness in pharmaceutical industry. In addition, we attempt to find out the level of enhancement sales force receive when they possess this skill sets.

\section{Hypothesis}

H1: Higher the technical skills, greater the level of sales force effectiveness

$\mathrm{H} 2$ : Higher the industry experience, higher level of technical skills

\section{Research Methodology}

The present study is a combination of both descriptive and analytical design. The sources of data, statistical methods and models used to analyse the collected data are shown below.

\subsection{Sampling Design}

In the study, the front line sales persons (i.e. the executives meeting their end users in branded pharmaceutical companies) participated in the survey. To collect the required data, a field survey method was adopted in getting the information. We used structured questionnaire to collect the data. Only $2^{\text {nd }}$ and $3^{\text {rd }}$ line managers formed as sample respondents. Non-probability sampling method was used in finalizing the sample respondents. A method called as accidental-quota sampling was adopted in narrowing down the sample size.

Total of 32 pharmaceutical front line sales executives participated in this survey to give their opinions. The study selected two States from India viz., Tamil Nadu and Karnataka for this survey. The survey took one year - March 2012 to January 2013 - to collect relevant information. We took sample of 352 respondents for this survey.

\subsection{Sample Size}

Pharmaceutical sales executives as members of Federal Medical Representatives Association of India come to around 85,000. In Tamil Nadu and Karnataka states of India, the registered number was 12,000 and 6,000 respectively. Of these total 18,000 pharmaceutical executives, we collected responses from 450 samples. Due to lack of information and other 
errors in the questionnaire, the present study considered only 352 respondents for the current research. There is no equal distribution of sample between these two States due to personal difficulty faced by the respondents in the survey. Hence, out of these 352 samples, 114 responses came from Karnataka and the remaining 238 sample from Tamil Nadu.

\section{Analysis of the Survey}

We tested the collected data through simple statistical tools. First, to understand the behaviour of sales people, we attempted to identify the composition of socio economic aspects and then moved towards the skill sets pattern among the respondents. The second set of analysis includes the factor analysis, which brings out the most important components to narrow down the skill sets, which then is followed by multiple regression to find the validity of factor analysis.

Table 1: Social-Economic Composition

\begin{tabular}{|l|c|c|c|}
\hline Category & Classification & No. of respondents & Percent \\
\hline \multirow{3}{*}{ Gender } & Male & 352 & 100 \\
\hline \multirow{4}{*}{ Age } & Total & 352 & 100 \\
\cline { 2 - 4 } & $<25$ & 47 & 13.4 \\
\cline { 2 - 4 } & $25-30$ & 184 & 52.4 \\
\cline { 2 - 4 } & $31-36$ & 108 & 30.8 \\
\cline { 2 - 4 } & $>36$ & 12 & 3.4 \\
\cline { 2 - 4 } & Total & 351 & 100 \\
\hline Educational qualification & Diploma & 28 & 8.0 \\
\cline { 2 - 4 } & Undergraduate & 272 & 77.3 \\
\cline { 2 - 4 } & Postgraduate & 52 & 14.8 \\
\cline { 2 - 4 } & Total & 352 & 46.0 \\
\hline Marital status & Married & 162 & 52.8 \\
\cline { 2 - 4 } & Unmarried & 186 & \\
\cline { 2 - 4 } & Total & 348 & \\
\cline { 2 - 4 } & & & \\
\hline
\end{tabular}

A total of 352 male respondents participated in this survey. Due to the nature of job which includes continuous and extensive travelling to cover the territory, work pressure in terms of meeting the customers and achieving the sales targets, etc. sales profession in India is highly dominated by men, which gets reflected in the survey as all the respondents are men. As found in the table, young men (25-30 years of age) dominated with 184 numbers in this study. Some 31 per cent were nearing their 40s. Thirteen per cent under age group of 25 also formed a group in this study.

Under Graduates formed 77 per cent followed by 15 per cent with post-graduation. Most of the leading pharmaceutical organizations offered entry-level job only to young graduates. In addition, 53 per cent are unmarried and 47 per cent married.

Table 2: Career Composition

\begin{tabular}{|l|c|c|c|}
\hline Category & Classification & No. of respondents & Percent \\
\hline \multirow{4}{*}{ Work Experience In Present Company } & $<5$ & 285 & 81.2 \\
\cline { 2 - 4 } & $5-10$ & 56 & 16.0 \\
\cline { 2 - 4 } & $>10$ & 10 & 2.8 \\
\cline { 2 - 4 } & Total & 351 & 100 \\
\hline \multirow{5}{*}{ Work Experience in Pharmaceutical Industry } & $<5$ & 169 & 48.1 \\
\cline { 2 - 4 } & $5-10$ & 128 & 36.5 \\
\cline { 2 - 4 } & $>10$ & 54 & 15.4 \\
\cline { 2 - 4 } & Total & 351 & 100 \\
\hline Number of Organizations Worked till date & $<1$ & 47 & 13.5 \\
\cline { 2 - 4 } & $1-3$ & 250 & 71.6 \\
\cline { 2 - 4 } & $>3$ & 52 & 14.9 \\
\cline { 2 - 4 } & Total & 349 & 100 \\
\cline { 2 - 4 }
\end{tabular}

The respondents expressed their professional experience, which is categorized in Table 2. Around 81 percent hold less 
than five years' experience in current position, followed with 16 percent respondents who hold 5 to 10 years' experience in the current position.

Less than 50 percent hold below five years' experience in pharmaceutical industry, but 36 percent had completed five to ten years in the same industry. It also disclosed around 15 percent having more than 10 years of pharma industry. Work experience in one to three organizations is with 71 percent of the respondents.

Table 3: Composition of Training Obtained:

\begin{tabular}{|l|c|c|c|}
\hline Category & Classification & No. of respondents & Percent \\
\hline Training in 2009 & $<1$ & 292 & 89.0 \\
\cline { 2 - 4 } & $1-3$ & 32 & 9.8 \\
\cline { 2 - 4 } & $>3$ & 4 & 1.2 \\
\cline { 2 - 4 } & Total & 328 & 100 \\
\hline Training in 2010 & $<1$ & 266 & 82.1 \\
\cline { 2 - 4 } & $1-3$ & 54 & 16.7 \\
\cline { 2 - 4 } & $>3$ & 4 & 1.2 \\
\cline { 2 - 4 } & Total & 328 & 100 \\
\hline Training in 2011 & $<1$ & 270 & 83.1 \\
\cline { 2 - 4 } & $1-3$ & 52 & 16.0 \\
\cline { 2 - 4 } & $>3$ & 3 & 0.9 \\
\cline { 2 - 4 } & Total & 325 & 100 \\
\hline
\end{tabular}

To evaluate the effectiveness of the front line pharma sales force, the respondents are asked to provide three years (2009, 2010 and 2011) details of the sales training programs (Table 3) they have attended in their organizations. In the year 2009, 89 percent of respondents have attended one sales training program. Likewise, in year 2010 and 2011, 83 percent attended minimum of one training program. In 2010 and 2011, around 16 percent attended more than one training program.

Table 4: Composition of Recognition Received:

\begin{tabular}{|l|c|c|c|}
\hline Category & Classification & No. of respondents & Percent \\
\hline Recognition in 2009 & $<1$ & 303 & 96.8 \\
\cline { 2 - 4 } & $1-2$ & 10 & 3.2 \\
\cline { 2 - 4 } & $>2$ & 0 & 0 \\
\cline { 2 - 4 } & Total & 313 & 100 \\
\hline Recognition in 2010 & $<1$ & 312 & 96.9 \\
\cline { 2 - 4 } & $1-2$ & 10 & 3.1 \\
\cline { 2 - 4 } & $>2$ & 0 & 0 \\
\cline { 2 - 4 } & Total & 322 & 92.7 \\
\hline Recognition in 2011 & $<1$ & 306 & 0 \\
\cline { 2 - 4 } & $1-2$ & 24 & 100 \\
\cline { 2 - 4 } & $>2$ & 0 & \\
\cline { 2 - 4 } & Total & 330 & \\
\cline { 2 - 4 } & & & \\
\hline
\end{tabular}

In table 4, recognitions received by the respondents are recorded. The recognitions in terms of both monetary and nonmonetary benefits included awards, promotions, incentives, cash prizes, etc. Most of the respondents received minimum recognition from their organization in all the three years. Compared with the year 2009 and 2010, they received minimum of one and maximum of two recognitions from their companies in 2011. 
Table 5: Composition of New Accounts Added:

\begin{tabular}{|l|c|c|c|}
\hline Category & Classification & No. of respondents & Percent \\
\hline New Accounts Added in 2009 & $<1$ & 116 & 37.3 \\
\cline { 2 - 4 } & $1-5$ & 172 & 55.3 \\
\cline { 2 - 4 } & $6-10$ & 16 & 5.1 \\
\cline { 2 - 4 } & $>10$ & 7 & 2.3 \\
\cline { 2 - 4 } & Total & 311 & 100 \\
\hline \multirow{5}{*}{ New Accounts Added in 2010 } & $<1$ & 48 & 15.3 \\
\cline { 2 - 4 } & $1-5$ & 242 & 77.1 \\
\cline { 2 - 4 } & $6-10$ & 22 & 7.0 \\
\cline { 2 - 4 } & $>10$ & 2 & 0.6 \\
\cline { 2 - 4 } & Total & 314 & 100 \\
\hline New Accounts Added in 2011 & $<1$ & 55 & 17.4 \\
\cline { 2 - 4 } & $1-5$ & 238 & 75.1 \\
\cline { 2 - 4 } & $6-10$ & 18 & 5.7 \\
\cline { 2 - 4 } & $>10$ & 6 & 1.9 \\
\cline { 2 - 4 } & Total & 317 & 100 \\
\hline
\end{tabular}

Considering the measurement of sales force effectiveness, the total number of new accounts generated by the sales persons during a specific year is one indicator for their effectiveness. In 2010 and 2011 , approximately 77.1 percent and 75.1 percent created minimum of one and maximum of five new accounts respectively in their territories. This when compared with 2009, is an improvement in getting new accounts. Creating new business and achieving targets automatically qualify the sales persons for recognitions from their organizations.

Table 6: Sampling Adequacy

\begin{tabular}{|c|c|c|c|}
\hline Factors & Cronbach's Alpha & KMO & Barlett's sphericity \\
\hline Technical Skills & 0.923 & 0.827 & 3120.071 \\
\hline
\end{tabular}

\subsection{Cronbach's alpha:}

A high value of 0.923 is due to considering 14 components for the analysis. A comfortable high Cronbach's alpha value as a reliability measure assures further factor extraction method, and the skill sets defined is suitable for analysis.

\subsection{Kaiser-Meyer-Olkin and Barlett's Sphericity measure:}

'Technical skill' received a high KMO score of 0.83 . Since it is more than 0.5 , it can be safely inferred that factor analysis can be carried out for the present research. In addition, Bartlett's sphericity is significant as it is $<0.0001$. Hence it is proved; that the components framed for the skill set is fit to go with factor analysis.

Table 7: Factor analysis - Technical skills

\begin{tabular}{|c|c|c|c|c|c|}
\hline $\begin{array}{l}\text { Technical Skills } \\
\text { Factors }\end{array}$ & Items & $\begin{array}{l}\text { Eigen } \\
\text { Value }\end{array}$ & \begin{tabular}{|c|} 
Factor \\
loadings
\end{tabular} & Communalities & \begin{tabular}{|l} 
Variance \\
Explained
\end{tabular} \\
\hline \multirow[t]{4}{*}{$\begin{array}{l}\text { Customer/Product } \\
\text { Knowledge }\end{array}$} & $1 \begin{array}{l}\text { Giving customers an accurate explanation of what the } \\
\text { product/service will do for them }\end{array}$ & \multirow{4}{*}{7.044} & .829 & .777 & \multirow{4}{*}{46.958} \\
\hline & 2 Influencing a customer by information rather than by pressure & & .759 & .689 & \\
\hline & \begin{tabular}{|l|} 
Knowledge of your own company's procedures \\
\end{tabular} & & .726 & .719 & \\
\hline & 4 Knowledge of product line, including product features and benefits & & .692 & .684 & \\
\hline \multirow[t]{4}{*}{$\begin{array}{l}\text { Competitive } \\
\text { Strength }\end{array}$} & 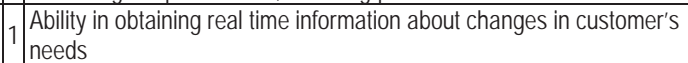 & \multirow{4}{*}{1.353} & .763 & .783 & \multirow{4}{*}{9.017} \\
\hline & 2 Knowledge of customer's plan & & .721 & .652 & \\
\hline & $3 \begin{array}{l}\text { Building the value based on organization's ability to deliver value- } \\
\text { based } \\
\text { Services during the selling process }\end{array}$ & & 679 & .733 & \\
\hline & 4 Level of knowledge about industry trends & & .586 & .569 & \\
\hline
\end{tabular}




\begin{tabular}{|c|c|c|c|c|c|}
\hline \multirow{4}{*}{\begin{tabular}{|l|} 
Client \\
Evaluation
\end{tabular}} & 1 Knowledge of competitors services & \multirow{4}{*}{1.196} & .852 & .765 & \multirow{4}{*}{7.974} \\
\hline & 2 Knowledge of competitors products & & .672 & .701 & \\
\hline & 3 Knowledge of competitors policies & & .650 & .761 & \\
\hline & 4 My success in understanding new projects in my territory & & .607 & .593 & \\
\hline \multirow[t]{2}{*}{$\begin{array}{l}\text { Organizational } \\
\text { Knowledge }\end{array}$} & 1 Training received from the organization in interacting effectively with & \multirow[t]{2}{*}{.897} & .819 & .753 & \multirow[t]{2}{*}{5.983} \\
\hline & 2 Understanding the potentiality of my customer & & .643 & .760 & \\
\hline
\end{tabular}

\section{Factor Analysis - Technical Skills}

To find the factors that determine technical skills, we applied factor extraction, which further gave 15 items as reasonable loadings that brought out four factors.

In communalities, it showed a reasonably high inter correlation between the four variables that summed up as the first factor. The four items with an eigen value $=7.044$ indicated that they had [(7.044/15 units of variance) (100)] 46.96 per cent explanatory power of variance. High factor loading among these variables were reason enough to extract the first factor and name them as 'Customer/Product Knowledge'.

The next set of communalities with four variables carried high value to create the second factor of technical skills that held determinable effect on sales force effectiveness. An eigen value of 1.353 showed that it hold explanatory power of 9.017 per cent [(1.353/15 units of variance) (100)]. We name these communalities as 'Competitive Strength'.

We created the third factor with the help of high communalities observed in the next four variables. These variables scored an eigen value of 1.196 , which amounted to $7.974 \%$ of variance explained. With high factor loading, the third factor is named as 'Client evaluation'.

The fourth factor with two extracted variables hold high communalities, but scored $<1$ in eigen value. This is less than the acceptable level of 1.0. That is, they had the power to explain less variance than a single variable could have done. This factor cannot be dropped, as this output is the result of extraction and rotation process adopted. With an explanatory power of 5.98 per cent, we decided to name this factor as 'Organisational knowledge'.

Table 8: Descriptive statistics - Technical Skills

\begin{tabular}{|l|l|c|c|c|c|c|}
\hline \multicolumn{2}{|l|}{ Technical skills Constructs } & No. of items & Mean(SD) & Skewness (SE) & Kurtosis(SE) & Cronbach'sAlpha \\
\hline 1 & Customer/product knowledge & 4 & $3.59(0.69)$ & $-0.23(.130)$ & $0.33(.259)$ & 0.84 \\
\hline 2 & Competitive strength & 4 & $3.31(0.66)$ & $-0.17(.130)$ & $0.26(.259)$ & 0.81 \\
\hline 3 & Client evaluation & 4 & $3.32(0.62$ & $0.13(.130)$ & $0.04(.259)$ & 0.82 \\
\hline 4 & Organisational knowledge & 2 & $3.57(0.79)$ & $-0.30(.130)$ & $0.97(.259)$ & 0.74 \\
\hline
\end{tabular}

The table 9 describes the descriptive statistics tested for technical skill sets. The mean and SD for all the factors indicate that respondents felt 'good' about these skill sets which had a role in building their efficiency level. As the SD for all the factors were < 1 , which indicates less deviation among the responses received. The first factor extracted 'Customer/product knowledge' had a mean score of $M=3.59(S D=0.69)$, followed by 'Competitive strength' ( $M=3.31$; $S D=0.66)$, 'Client evaluation' $(M=3.32 ; S D=0.62)$, 'Organisational knowledge' $(M=3.57 ; S D=0.79)$

To measure the normality of distribution of the composite scores of the extracted factors, skewness and kurtosis tests were used and the result showed that 'Customer/product knowledge' had a skewness value of $-0.23(\mathrm{SE}=.130)$ and kurtosis value of $0.33(\mathrm{SE}=.259)$. We observed similar kind of result for other remaining factors. 'Competitive strength' had a skewness value of $-0.17(\mathrm{SE}=.130)$ and kurtosis value of $0.26(\mathrm{SE}=.259)$, 'Client Evaluation' had $0.13(\mathrm{SE}=.130)$ and $0.04(\mathrm{SE}=.259)$, 'Organizational knowledge' had $-0.30(\mathrm{SE}=.130)$ and $0.97(\mathrm{SE}=.259)$ respectively. Examinations of the histograms suggest distribution is approximately normal and suitable for further parametric tests.

The Cronbach's alpha value for all four factors indicated high reliability as they hold value of more than 0.60 , 'Customer/product Knowledge' ( $a=0.841$ ), 'Competitive strength' ( $a=0.806$ ), 'Client evaluation' $(a=0.818)$, and 'Organisational knowledge' $(a=0.741)$. This further consolidates that the results obtained from factor analysis is appropriate for further tests. 
Table 9: Ordinary Least Square (OLS) estimation of working experience and Technical Skills

\begin{tabular}{|c|c|c|c|c|c|}
\hline \multirow[b]{2}{*}{ Dependent Variable } & \multicolumn{3}{|c|}{ Independent Variable } & \multirow[b]{2}{*}{$\mathbf{R}^{2}$} & \multirow[b]{2}{*}{$\mathbf{F}$} \\
\hline & $\begin{array}{c}\text { Industry working } \\
\text { Experience }\end{array}$ & $\begin{array}{c}\text { Number of organization } \\
\text { worked }\end{array}$ & $\begin{array}{c}\text { Present organization } \\
\text { experience }\end{array}$ & & \\
\hline Customer/Product Knowledge & $\begin{array}{l}-.048 \\
(-.065)\end{array}$ & $\begin{array}{c}.036 \\
(.578) \\
\end{array}$ & $\begin{array}{c}.114 \\
(1.576) \\
\end{array}$ & .009 & .989 \\
\hline Competitive Strength & $\begin{array}{c}-.078 \\
(-1.001)\end{array}$ & $\begin{array}{l}.230^{*} \\
(3.750)\end{array}$ & $\begin{array}{c}.101 \\
(1.427)\end{array}$ & .046 & 5.477 \\
\hline Client Evaluation & $\begin{array}{c}.112 \\
(1.427)\end{array}$ & $\begin{array}{l}-174^{*} \\
(-2.805)\end{array}$ & $\begin{array}{l}.003 \\
(.043)\end{array}$ & . $027 \mid$ & 3.143 \\
\hline Organization Knowledge & $\begin{array}{l}-.061 \\
(-.847)\end{array}$ & $\begin{array}{c}.145 \\
(1.833)\end{array}$ & $\begin{array}{l}-128^{*} \\
(-2.059)\end{array}$ & & 1.762 \\
\hline
\end{tabular}

The OLS explains the influence of work experience on technical skills. The results indicate two regression equations with reasonable goodness of fit with significant $F$ value.

The competitive strength (5.47) and client evaluation (3.14) hold significant variables. The explanatory power ( $\left.\mathrm{R}^{2}\right)$ value is low for all equations.

The beta coefficient value of 'Number of Organization worked' is significant with two factors namely competitive strength $(b=0.23, t=3.75)$ and client evaluation $(b=-0.17, t=-2.80)$. This shows that for every one per cent increase in experience with 'Number of Organization Worked' improves the 'Competitive Strength' by 23 per cent. However, we find considerable (i.e., $1 \%$ ) working experience with different Organization reduced capability of 'Client Evaluation' by 17 per cent. This result is surprising, since in reality evaluating a customer significantly improves with more work experience.

The fourth equation showed that 'Organization knowledge' declined by 13 per cent for every one per cent increase in working experience in present Organization. This also shows a completely different scenario. Knowledge about the organization where these sales persons are working is very low even after putting significant years in service.

Therefore, we find only 'competitive strength' as the only technical skill which qualifies to enhance sales force effectiveness.

Table 10: Ordinary Least Square Estimation of Technical skills with Sales Target

\begin{tabular}{|c|c|c|c|c|c|c|}
\hline \multirow[b]{2}{*}{ Dependent Variable } & \multicolumn{4}{|c|}{ Independent Variable } & \multirow[b]{2}{*}{$\mathbf{R}^{2}$} & \multirow[b]{2}{*}{$\mathrm{F}$} \\
\hline & $\begin{array}{c}\text { Customer/ Product } \\
\text { Knowledge }\end{array}$ & $\begin{array}{c}\text { Competitive } \\
\text { Strength }\end{array}$ & $\begin{array}{c}\text { Client } \\
\text { Evaluation }\end{array}$ & $\begin{array}{c}\text { Organization } \\
\text { Knowledge }\end{array}$ & & \\
\hline Sales Target 2009 & $\begin{array}{c}-.032 \\
(-.582)\end{array}$ & $\begin{array}{l}.010 \\
(.188)\end{array}$ & $\begin{array}{c}.097 \\
(1.775)\end{array}$ & $\begin{array}{c}-.036 \\
(-.665)\end{array}$ & .012 & 1.014 \\
\hline Sales Target 2010 & $\begin{array}{c}-.058 \\
(-1.075) \\
(-1.075\end{array}$ & $\begin{array}{c}-.028 \\
(-.512) \\
\end{array}$ & $\begin{array}{l}.048 \\
(.887)\end{array}$ & $\begin{array}{c}.059 \\
(1.079) \\
\end{array}$ & .010 & .849 \\
\hline Sales Target 2011 & $\begin{array}{c}.004 \\
(-.083)\end{array}$ & $\begin{array}{c}.069 \\
(1.269)\end{array}$ & $\begin{array}{c}-.032 \\
(-.589)\end{array}$ & $\begin{array}{c}.032 \\
(.593)\end{array}$ & .007 & .560 \\
\hline
\end{tabular}

The numbers in table 11 reflects very week $F$ and $R^{2}$ value. Goodness of fit for all the equation is missing (low $F$ value). The beta coefficient for the entire model is insignificant and is not fit for interpretation. The only conclusion we draw from this model is Technical skills do not have any significant role in achieving sales targets.

Table 11: Ordinary Least Square Estimation of Technical skills with Net account added

\begin{tabular}{|c|c|c|c|c|c|c|}
\hline \multirow[b]{2}{*}{ Dependent Variable } & \multicolumn{4}{|c|}{ Independent Variable } & \multirow[b]{2}{*}{$\mathbf{R}^{2}$} & \multirow[b]{2}{*}{$\mathbf{F}$} \\
\hline & $\begin{array}{c}\text { Customer/ Product } \\
\text { Knowledge }\end{array}$ & $\begin{array}{c}\text { Competitive } \\
\text { Strength }\end{array}$ & $\begin{array}{c}\text { Client } \\
\text { Evaluation }\end{array}$ & $\begin{array}{c}\text { Organization } \\
\text { Knowledge }\end{array}$ & & \\
\hline Net Account Added 2009 & $\begin{array}{c}.052 \\
(.910)\end{array}$ & $\begin{array}{c}-.064 \\
(-1.110)\end{array}$ & $\begin{array}{l}.040 \\
(.696)\end{array}$ & $\begin{array}{l}.016 \\
(.277)\end{array}$ & .009 & .662 \\
\hline Net Account Added 2010 & $\begin{array}{c}.076 \\
(1.334)\end{array}$ & $\begin{array}{c}-.069 \\
(-1.209)\end{array}$ & $\begin{array}{c}-.047 \\
(-.826)\end{array}$ & $\begin{array}{c}-.045 \\
(-.795)\end{array}$ & .015 & 1.169 \\
\hline Net Account Added 2011 & $\begin{array}{c}-.084 \\
(-1.474)\end{array}$ & $\begin{array}{c}.025 \\
(-.447)\end{array}$ & $\begin{array}{c}-.063 \\
(-1.109)\end{array}$ & $\begin{array}{l}-.034 \\
(-.596)\end{array}$ & .011 & .888 \\
\hline
\end{tabular}


The OLS model as shows in table 12 is not fit for further explanation as all the required numbers is found very week. We interpret this as new account added by sales persons is not due to their technical skills.

Table 12: Ordinary Least Square Estimation of Technical skills with Sales Training attended by sales persons

\begin{tabular}{|c|c|c|c|c|c|}
\hline \multirow{2}{*}{ Dependent Variable } & \multicolumn{3}{|c|}{ Independent Variable } & \multirow{2}{*}{$\mathbf{R}^{2}$} & \multirow{2}{*}{$\mathrm{F}$} \\
\hline & Training 2009 & Training 2010 & Training 2011 & & \\
\hline Customer/Product Knowledge & $\begin{array}{c}.055 \\
(.870) \\
\end{array}$ & $\begin{array}{c}-.055 \\
(-.504) \\
\end{array}$ & $\begin{array}{c}-.111 \\
(-1.020)\end{array}$ & .021 & 2.148 \\
\hline Competitive Strength & $\begin{array}{c}-.155^{*} \\
(-2.460)\end{array}$ & $\begin{array}{c}-.197 \\
(-1.831)\end{array}$ & $\begin{array}{c}.201 \\
(1.851)\end{array}$ & .035 & 3.653 \\
\hline Client Evaluation & $\begin{array}{c}-.061 \\
(-.954) \\
\end{array}$ & $\begin{array}{c}.107 \\
(.975) \\
\end{array}$ & $\begin{array}{c}-.076 \\
(-.687) \\
\end{array}$ & .006 & .569 \\
\hline Organization knowledge & $\begin{array}{c}-.032 \\
(-.499)\end{array}$ & $\begin{array}{c}187 \\
(1.715)\end{array}$ & $\begin{array}{c}-1.175 \\
(-1.597)\end{array}$ & .011 & 1.104 \\
\hline
\end{tabular}

Table 13 explains OLS model between training attended by sales persons and their technical skills. Of the four equations fitted for this model, only the second equation with "Competitive Strength" as dependent variable turned out with reasonable explanatory power. This again showed an unexpected result. Training received in 2009 did reduce the 'competitive strength' by 15 per cent. The interpretation we try to draw from this result is that more than training, there are other factors, which act as motivating factor to enhance the technical skills of sales people.

Table 13: Ordinary Least Square Estimation of Technical skills with Sales persons' recognition received

\begin{tabular}{|c|c|c|c|c|c|}
\hline \multirow{2}{*}{ Dependent Variable } & \multicolumn{3}{|c|}{ Independent Variable } & \multirow{2}{*}{$\mathbf{R}^{2}$} & \multirow[b]{2}{*}{$\mathbf{F}$} \\
\hline & Recognition 2009 & Recognition 2010 & Recognition 2011 & & \\
\hline Customer/Product Knowledge & $\begin{array}{c}-.168^{*} \\
(-2.245)\end{array}$ & $\begin{array}{c}-.157^{*} \\
(-2.789)\end{array}$ & $\begin{array}{c}.008 \\
(.103)\end{array}$ & .049 & 5.230 \\
\hline Competitive Strength & $\begin{array}{l}-.059 \\
(.777) \\
\end{array}$ & $\begin{array}{c}.062 \\
(1.091)\end{array}$ & $\begin{array}{c}-.035 \\
(-.455)\end{array}$ & .012 & 1.201 \\
\hline Client Evaluation & $\begin{array}{c}-.051 \\
(-.675)\end{array}$ & $\begin{array}{c}.039 \\
(.675)\end{array}$ & $\begin{array}{c}-.058 \\
(-.763)\end{array}$ & .012 & 1.205 \\
\hline Organization knowledge & $\begin{array}{c}-.060 \\
(-.790)\end{array}$ & $\begin{array}{c}-.033 \\
(-.571) \\
-(.5)\end{array}$ & $\begin{array}{c}-.078 \\
(-1.019)\end{array}$ & .016 & 1.683 \\
\hline
\end{tabular}

The OLS estimation between recognition received and technical skills exhibit poor model fit. Except for the dependent variable - 'Customer/Product Knowledge' - other dependent variables did not get significant $\mathrm{F}$ value. Coefficient values of the last three equations are not interpretable due to insignificance. Beta value of recognition in 2009 and 2010 is significant at five per cent level. However, the meaning is not useful for the present study.

Recognition awarded in 2009 if increases by one per cent, sales person knowledge about customer and product declined by 17 per cent. It declined by 16 per cent when they received the recognition in 2010. It reveals that recognition and awards given to sales people do not have any significance in enhancing the 'Technical Skills'.

\section{Proving of Hypothesis}

\subsection{Higher the technical skills, greater the level of sales force effectiveness}

Technical skills reflected through 'Competitive Strength' improved if sales person had worked in more organizations, but it declined when they were given training. Skill sets like 'Client Evaluation', 'Organization Knowledge' and 'Customer/Product Knowledge' saw a decline when regressed with organization worked, work experience in present firms, and awards/recognition. Further, as dependent variables, these technical skill sets failed to improve achievement of sales target and adding up new accounts to the firm. Hence, we disprove the hypothesis. 


\subsection{Higher the industry experience, higher level of technical skills}

Work experience in more number of organizations did improve 'Competitive Strength' but it stops there. Experience in the present organization and same industry failed to enhance the technical skills. As we consider all four components as important criteria for terming technical skills, the hypothesis is rejected.

\section{Conclusion}

The Sales person's efficiency is the base for achieving sales targets. This efficiency is not inherited by these people, but are gained and sharpened by the amount of effort put by these executives. Various studies had found that some specified skill sets are prerequisite for the sales people to perform well in the market. These skills are also found among the executives of a pharmaceutical company.

The study had traced the influencing level of technical skills of a front line sales force of branded pharmaceutical products. From the study it is found that Customer/Product knowledge; Competitive knowledge and Client evaluation are important criteria for Technical skill set. Through a simple statistical analysis, the study found that, 'Competitive Strength' plays a significant role in enhancing the sales force of a company.

There is good scope for this study when this is extended with different segments. For example, purely on multinational organizations, Indian based multinationals, surgical markets, diagnostic segment, medical equipment's, etc. Similarly, comparison of two different pharmaceutical segments' sales force effectiveness can be undertaken. Furthermore, depth of the sales force skills can be measured by adding additional dimensions of the sales skill sets. Another dimension of this study can be conducted in the areas like key accounts management (KAM) and Institutional business. Hence the scope is far reaching as the present study had proved which could be taken for further test exclusively in Tier I, II and III cities as these markets are found to be different in terms of consumptions and exposure of the pharmaceutical products.

\section{References}

Babakus, E., Cravens,D.W.,Grant, K., Ingram, T.N. and Laforge, R.W.(1996). Investigating the Relationship among Sales Management Controls, Sales Territory Design, Salesperson Performance, and Sales Organization Effectiveness, International Journal of Research in Marketing, 13(4), 345-363.

Baldauf, A., Cravens, D. (1999). Improving the effectiveness of field sales organizations, Industrial Marketing Management, Vol.28, pp.63-72

Baldauf, A., Cravens, D. and Piercy, N. (2001a). Examining the consequences of sales management control strategies in European field sales organizations, International Marketing Review, Vol.18, No.5, pp.474-508

Churchill, G., Ford, N. and Walker, O. (1993). Direccion de ventas, Promociones Jumerca, Valencia

Churchill, G., Ford, N. and Walker, O. Johnson, M.W. and Tanner, J.F. (2000). Sales Force Management, 6th ed., McGraw-Hill, Boston, MA

Churchill, G., Ford, N.M., Hartley, S.W. and Walker, O.C. (1985). The determinants of sales person performance: a meta-analysis, Journal of Marketing Research, Vol. XXII, May, pp.103-118

Cravens. D., Ingram, T., Laforge, R. and Young, C. (1993), Behavior-based and outcome-based sales force control systems, Journal of Marketing, Vol.57, October, pp.47-59

Hultink, E. J. \& Atuahene-Gima, K. (2000). "ThA. Tansu Barker, (2001). Salespeople characteristics, sales managers" activities and territory design as antecedents of sales organization performance, Marketing Intelligence \& Planning, Vol. 19 Iss: 1, pp.21 - 28.

Ines Kuster and Pedro Canales(2008). Some Determinants of Sales force Effectiveness, Team Performance Management, Vol.14, No.7/8, pp.296-326

Mohd Sah Basir, Syed Zamberi Ahmed and Philip J. Kitchen,(2010). The Relationship between Sales Skills and Salesperson Performance, International Journal of Management and Marketing Research, Vol.3, No.1, pp.51-70.

Oliver, Richard and Erin Anderson (1994). An Empirical Test of Consequences of Behavior and Outcome Based Sales Control Systems, Journal of Marketing, Vol.58 (October), 53-67.

Pekka Töytäri, Thomas Brashear Alejandro, Petri Parvinen, Ilmari Ollila, Nora Rosendahl (2011). Bridging the theory to application gap in value-based selling, Journal of Business \& Industrial Marketing, Vol. 26 Iss: 7, pp.493 - 502

Pierchy, N., Cravens, D. and Lane, N (2001). Sales manager behavior control strategy and its consequences: the impact of gender differences, Journal of Personal Selling and Sales Management, Vol.XXI NO.1, pp.39-49

Piercy, N., Cravens, D. and Morgan, N. (1997). Sources of effectiveness in the business to business sales organization, Journal of Marketing Practice: applied Marketing Science, Vol.3, No.1, pp.43-69

Rapp, A., Agnihotri, R., Forbes, L.P. (2008). The sales force technology-performance chain: the role of adaptive selling and effort, Journal of Personal Selling \& Sales Management, vol.28, No.4, pp.335-50 
Rapp, A., Agnihotri, R., Forbes, L.P. (2008). The sales force technology-performance chain: the role of adaptive selling and effort, Journal of Personal Selling \& Sales Management, vol.28, No.4, pp.335-50

Roman. S., Ruiz, S. and Munuera, J.L. (2002). The effects of sales training on sales force activity, European Journal of Marketing, Vol.36, No11/12, pp.1344-66

Ryans, A. B. and Weinberg, C. B. (1981). Sales force Management: Integrating Research Advances, Vol. XXIV, fall, No.1, pp. 75-89 